\title{
Optimization of Fermentation Conditions for Ethanol Production from Renewable Biomass Using Response Surface Methodology Shashank Tripathi*
}

Department of Bioengineering and Biosciences, Lovely Professional University, Punjab, India

\begin{abstract}
Potato Peel Waste (PPW) is a potential lignocellulosic biomass substrate for bioethanol production due to its high starch content and easy availability. In this study, we performed research optimization of fermentation process by Response Surface Methodology (RSM) using Plackett-Burman design. The process herein included acid-base pre-treatment of biomass, which was then followed by enzymatic hydrolysis as a potential step. The concentration of reducing sugar in the hydrolysate thus obtained was then analyzed by DNSA method. After fermenting the hydrolysate with Saccharomyces cerevisiae for several days, distillation was done. Analysis of hydrolysate was done by FTIR. Pre-treatment is used for lignocellulosic biomass for improving the hydrolysis of the potato as it contains a high amount of cellulose and removal of lignin and hemicellulose. Cellulose converts into the reducing sugars and then to ethanol. Saccharification and fermentation methods were performed to acquire maximum yield of ethanol. The potato peels were pre-treated with Sulphuric acid and sodium hydroxide solutions.
\end{abstract}

Keywords: Bioethanol; Process optimization; Response surface methodology; Potato peel waste; Hydrolysis

\section{Introduction}

The natural resources are limited in supply, but the demand for energy is increasing day by day. Also burning of fossils fuels releases large amount of $\mathrm{CO}_{2}$ into the atmosphere which is the cause of increase in global temperature. In order to overcome all these problems, we need to look for all the available alternate energy resources. The ethanol production market worldwide grew from nearly a billion liters in 1975 to more than almost 39 billion liters in 2006 and is further about to reach upto 100 billion liters in 2025. In the present scenario, production of bioethanol is through extraneous sources like sugar cane juice, sugar beets, cereals, organic waste and cellulosic feedstock.

Production of ethanol from glycerol, glycerol-containing waste products, discharged from biodiesel manufacturing can be converted into hydrogen and ethanol by usage of Enterobacter aerogenes HU101 as the suitable organism, isolated primarily as increased-rate hydrogen producers from methanogenic sludge wastes. The ethanol concentration yield reported has been low, although many organisms in nature have been ideally identified as potential producers of ethanol that uses glycerol as substrate/source. Hao et al. [1] also isolated different microorganisms with potential of producing 1,3-propanediol by fermenting glycerol in aerobic conditions. But, the literary evidence regarding the aforesaid screening of potential microorganisms helpful in bio-conversion of glycerol into ethanol is highly limited.

The concept of "Second generation" bioethanol, with usage of lignocellulosic material as a primary feedstock, is a very potential alternative in contrary to first generation bioethanol. An overview study of the current status of bioethanol production reveals the bottlenecks that hamper its implementative processing and analysis. As part of the ongoing research and the literature provided by far specifies a method of conversion of biomass to bioethanol of 30 to $~ 50 \%$ yield only. Substantial novel processes have increased the conversion yield to up to $92 \%$ of the theoretical yield provided. These new combined processes thereby greatly reduce both the number of method-operational steps and the simultaneous production of inhibitors.

Recent research progress in genetically-modified microorganisms is highly promising in terms of increased alcohol tolerance and potential conversion efficiency. As a result, combining advanced research systems and by intensive research expertise to eliminate current congestion, naive second-generation biofuels (bioethanol) could efficiently surpass the traditional first-generation processes. In the present study, we investigate the co-production of bioethanol and probiotic yeast biomass from enzyme-pretreated grass juice. In addition to it, there has been a primary interest in the usage of lignocellulosic biomass from agriculture-related products as potential resource for the wide scale production of bioethanol(biofuel), more importantly because of the ever-increasing price rate for crop production and harvesting (e.g. corn, rice, etc.).

With reference to above stated, sugar cane bagasse and/or its products wheat straw husks, rice straw residues, corn stover, corncob products and also corn hull (i.e., corn fiber) are at present being researched investigated for their usage as important sources of highquality bioethanol production [2-5]. Until now, as reported by their fermentable sugar composition, required optimal fermentation processes, and methods/strategies for their resulting hydrolysates have been examined. Before the bioethanol fermentation process, acid hydrolysis as a pre-treatment step of these byproducts has been carried out by using dilute range solutions of sulfuric acid (in particular), and phosphoric acid, or hydrochloric acid [2-4]. Addition to this acid hydrolysis, utilization of enzymatic hydrolysis as the next potential step and under combined hydrolysis methodologies using both the enzymes and dilute acids has been reported. Corn hull is a residue produced from the corn wet-milling process. Its sugar composition varies (glucose 10 50\%, xylose 13 49\%, arabinose 10 31\%, and

"Corresponding author: Tripathi S, Department of Bioengineering and Biosciences, Lovely Professional University, Punjab, India, Tel: +91 7905144029; E-mail: shashankinsaan912@gmail.com

Received July 13, 2018; Accepted September 24, 2018; Published September 30, 2018

Citation: Tripathi S (2018) Optimization of Fermentation Conditions for Ethanol Production from Renewable Biomass Using Response Surface Methodology. J Pet Environ Biotechnol 9: 379. doi: 10.4172/2157-7463.1000379

Copyright: (c) 2018 Tripathi S. This is an open-access article distributed under the terms of the Creative Commons Attribution License, which permits unrestricted use, distribution, and reproduction in any medium, provided the original author and source are credited. 
Citation: Tripathi S (2018) Optimization of Fermentation Conditions for Ethanol Production from Renewable Biomass Using Response Surface Methodology. J Pet Environ Biotechnol 9: 379. doi: 10.4172/2157-7463.1000379

Page 2 of 9

galactose 3 10\%) depending on its origin, hydrolysis method, and corn processing method. Nowadays, most corn hull is used as animal feedstuff, and its utilization for bioethanol production has only recently been examined. Bioethanol provides a very good substitute as it can be produced from present fermentation technology.

Potato peel utilization for bioethanol production is a considerable option as $58 \%$ of the dry weight is starch. Three types of fermentation process (batch, fed-batch, and continuous) are employed in ethanol production from these sugar juices. The most common microorganism used in fermentation from its history is the yeast, especially, Saccharomyces cerevisiae, though the bacterial species Zymomonas mobilis is also potentially used nowadays for this purpose. A number of factors related to the fermentation greatly influence the process and their optimization is the key point for efficient ethanol production from this feedstock. The several steps involved in production of ethanol are listed (Figure 1).

The important thing required for production of ethanol from peels is the efficient yield fermentable hydrolysate rich in glucose. Enzymatic hydrolysis although costly, but provides better yield in future. Pretreatment methods are employed to increase efficiency of enzymatic hydrolysis. There are basically two pre-treatment methods physical and chemical methods. Of which acid-base hydrolysis is one of the most common methods followed by enzymatic hydrolysis. In which mineral acid is used in very low concentration.

\section{Analysis}

\section{FTIR (Fourier Transfer Infrared Spectroscopy)}

In the electromagnetic spectrum infrared region lies between visible and microwave region. The energy associated with molecular vibration fall in the IR region as they are lower than electronic transition. A molecular vibration absorbs IR radiation if the vibration causes change in dipole moment.

FTIR is used to identify organic molecules. Absorption by the molecules is measured against wavelength. An FTIR uses an interferometer which generates radiation; absorption of wavelength

\begin{tabular}{|l|l|l|}
\hline Bond & Molecules & Wavenumber $\mathbf{( c m}^{-1} \mathbf{~}$ \\
\hline $\mathrm{C}-\mathrm{O}$ & $\begin{array}{l}\text { Alcohols, Ethers, Esters, Carboxylic } \\
\text { Acids, etc. }\end{array}$ & $1300-1000$ \\
\hline $\mathrm{C}=\mathrm{O}$ & $\begin{array}{l}\text { Aldehydes, Ketones, Esters, Carboxylic } \\
\text { Acids. }\end{array}$ & $1750-1680$ \\
\hline $\mathrm{C}=\mathrm{O}$ & Amides & $1680-1630$ \\
\hline $\mathrm{N}-\mathrm{H}$ (stretching) & Amines and Amides & $3500-3100$ \\
\hline$-\mathrm{N}-\mathrm{H}$ (bending) & Amines and Amides & $1640-1550$ \\
\hline $\mathrm{O}-\mathrm{H}$ & Alcohols & $3650-3200$ \\
\hline $\mathrm{C}-\mathrm{N}$ & Amines & $1350-1000$ \\
\hline $\mathrm{S}-\mathrm{H}$ & Mercaptans & 2550 \\
\hline
\end{tabular}

Table 1: Typical vibrational frequencies of functional groups.

brings change in interferogram which gets detected. An interferogram is a time domain signal and is converted to frequency domain signal though Fourier Transformation. FTIR plots are usually \% transmittance or absorbance versus wave number. Absorption bands in 4000-1500 $\mathrm{cm}^{-1}$ are generally due to functional groups, peaks below this region are due to complex vibrations of several atoms (Table 1). The sample can be used in different forms (solid, liquid or gaseous) depending upon the instrumentation used.

\section{Reducing sugar estimation}

3,5-Dinitrosalicyclic acid used for reducing sugars estimation, involves oxidation of free carbonyl groups. DNSA is reduced to 3,5-amino-nitrosalicyclic acid which gives reddish brown color complex under alkaline conditions, with an absorbance maximum at $540 \mathrm{~nm}$ (Figure 2).

\section{Response surface methodology}

The study employed Response Surface Methodology for optimization of different conditions that affect fermentation temperature, acid concentration for hydrolysis, etc. Response surface method provides us scope for improvement and optimization of the desired response which is influenced by various variables [6]. Response surface methodology is defined as collection of techniques,

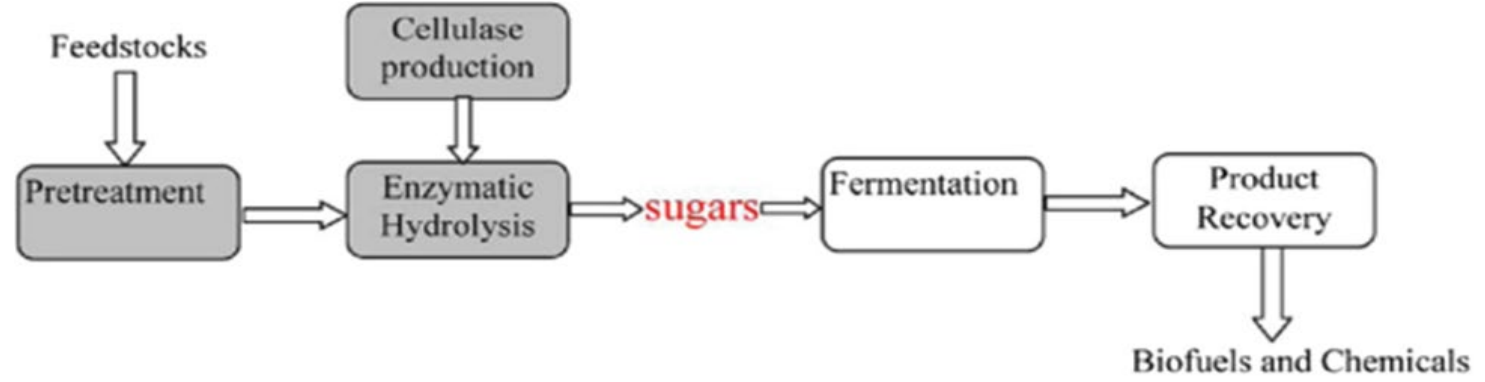

Figure 1: Process flow diagram.<smiles>O=C(O)c1cc([N+](=O)[O-])cc([N+](=O)[O-])c1O</smiles>

3,5-dinitrosalicylic acid (yellow)

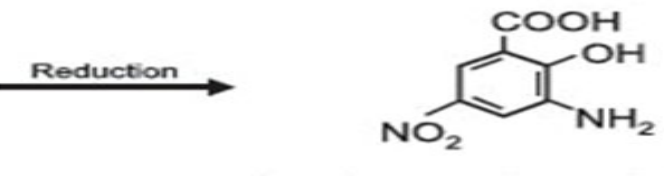

3 amino, 5-nitro salicylic acid (orange-red)

Figure 2: DNSA treatment. 
mathematical and statistical both based on polynomial equation fit of the experimental data. The objective of this technique is to simultaneously optimize levels of variables for best possible results. Stages involved in RSM are as follows:

- Screening of variables - It is very difficult to study all the variables affecting the response. Therefore, the variables with major effect are selected.

- Choice of experimental design - A good experimental designs ensures that all variables are studied at three factor levels.

- Mathematical statistical treatment of data.

- Evaluation of fitted model.

\section{Literature Review}

The study discusses the issue of pre-treatment of lignocellulosic biomass so that desired sugar yield is obtained after enzymatic treatment. They performed consecutive dilute sulfuric acid-dilute $\mathrm{NaOH}$ treatment on Sugarcane bagasse. This enhanced the cellulase accessibility in embedded cellulose microfibrils [7]. Production of ethanol from potato pulp is mainly influenced by starch hydrolysis into monosaccharide. $\alpha$-amylase and amyloglucosidase concentration affects hydrolysis greatly. The size of pulp and its concentration also influence hydrolysis [8]. Study on the very least studied Pichia veronae, to find optimum condition of ethanol production from this organism by response surface methodology based on central composite design [9]. This study basically focuses on utilization of high amount sweet potato residues generated in China for ethanol production. They studied various enzyme systems performance on SPRs hydrolysis and also role of cellulase and pectinase in it [10]. This study is about upscaling of bioethanol and bio hydrogen production from Enterobacter aerogenes under semi-anaerobic conditions. Different conditions like fresh feed rate, liquid recycling etc. optimization was done to find the best possible conditions [11]. The study done utilized RSM and central composite face centered design to find best possible condition to maximize ethanol production in batch fermentation from sugarcane molasses using Saccharomyces cerevisiae Y-39 [12] The paper focuses on feasibility of outdoor cultivation of carbohydrate rich microalgae Scenedesmus obliquus CNW N and its use as feedstock for ethanol production in long term batch operation. They studied time profile of content of carbohydrate under deficient conditions of nitrogen to check seasonal changes [13]. Water hyacinth is one of the most invasive weed of the world but die its high availability and large carbohydrate content it is also shows the ability to be a potential substrate for bioethanol production. In this study they tried to find out the solution of the problems associated with its hydrolysis and fermentation process. Pre-treatment of raw material and simultaneous saccharification and fermentation resolved both of the problems [14]. Pagnum harmala is a pharmaceutically important plant whose extract contains products of therapeutical effect but the leaves cannot be used as feed stock. So, they conducted studies to find optimal conditions to utilize this plant for ethanol production. Optimization of hydrolysis conditions were done with the help of response surface methodology and three levels Box-Behnken design [15]. Bioethanol production from algal biomass is a promising technology of future. Commercialization depends on the efficient production of monomeric sugars which will act as substrate for ethanol production. This paper used microalga Microcystis aeruginosa for optimization of pre-treatment and ethanol production. Pre-treatment with $\mathrm{CaO}$ before enzyme hydrolysis increases reducing sugar content for fermentation. A combination of microorganisms was used for fermentation [16]. The paper discusses the possibility of simultaneous utilization of glucose and xylose by Saccharomyces cerevisiae for production of ethanol on large scale,

\begin{tabular}{|c|c|c|c|c|c|}
\hline S. No. & Biomass & Organism used & Optimal cond. & Productivity (g/l/h) & Reference \\
\hline 1 & Sugarcane molasses & Pichia veronae Strain HSC-22 & $\mathrm{pH}-5-5.5 \mathrm{Temp}-30^{\circ} \mathrm{C}$ & 32 & Hamoud et al. [10] \\
\hline 2 & Potato waste & T. reesei & $45^{\circ} \mathrm{C}$ & 73.37 & Fangzhong Wang et al. [11] \\
\hline 3 & Biodiesel-Based Glycerol & Enterobacter aerogenes & pH-6.4 Temp $-37^{\circ} \mathrm{C}$ & -- & $\begin{array}{c}\text { Rujira Jitrwung and Viviane } \\
\text { Yargeau [12] }\end{array}$ \\
\hline 4 & Sugarcane Molasses & Saccharomyces cerevisiae & $\mathrm{pH}-5.6$ Temp $-38^{\circ} \mathrm{C}$ & -- & El-Gendy et al. [13] \\
\hline 5 & Microalgae & 2CVZ.mobilis & $\mathrm{pH}-6.0$ Temp $-30^{\circ} \mathrm{C}$ & 8.18 & Shih-Hsin Ho et al. [22] \\
\hline 6 & Gracilaria & Saccharomyces cerevisiae & -- & $4.93 \mathrm{~g} / \mathrm{l} / \mathrm{d}$ & Fang chan wu et al. [20] \\
\hline 7 & Lignocellulosic & Saccharomyces cerevisiae & -- & -- & Chen et al. [14] \\
\hline 8 & Miscanthus $x$ giganteus & S. stipitis & $\mathrm{pH}-4.8-5.0$ temp $-45-50^{\circ} \mathrm{C}$ & 0.13 & Mohd Azhar et al. [23] \\
\hline 9 & Water Hyacinth & Saccharomyces cerevisiae & $38.87^{\circ} \mathrm{C}$ & 1.289 & Zhang et al. [14] \\
\hline 10 & Glycerol & E. coli & $37^{\circ} \mathrm{C}$ & 6.5 & Suhaimi et al. [24] \\
\hline 11 & Lignocellulosic & $\begin{array}{l}\text { Saccharomyces } \\
\text { Cerevisiae }\end{array}$ & $\mathrm{pH}-5.0-6.0$ Temp $-25-35^{\circ} \mathrm{C}$ & 1 & Saini et al. [25] \\
\hline 12 & Wheat straw & Pichia stipitis NRRL Y-7124 & $\mathrm{pH}-2.0-7.0 \mathrm{Temp}-25-35^{\circ} \mathrm{C}$ & Yield- $0.35 \mathrm{~g} / \mathrm{g}$ & Saini et al. [26] \\
\hline 13 & Green seaweed & Cladosporium sphaerospermum & $\mathrm{pH}-4.0$ Temp $-25^{\circ} \mathrm{C}$ & Yield $-0.47 \mathrm{~g} / \mathrm{g}$ & Trivedi et al. [28] \\
\hline 14 & Corn Stover & Phlebia brevispora & $28^{\circ} \mathrm{C}$ & Yield $-38.0 \pm 0.2 \mathrm{~g} / \mathrm{g}$ & Saha et al. [29] \\
\hline 15 & P. harmala biomass & $\begin{array}{l}\text { Saccharomyces } \\
\text { cerevisiae }\end{array}$ & -- & Yield $-4.7 \%$ & Neifar et al. [15] \\
\hline 16 & Biomass of Microcystis aeruginosa & $\begin{array}{c}\text { S. cerevisiae, K. oxytoca, } \\
\text { B. custersainus and P. stipites. }\end{array}$ & -- & $60 \mathrm{~m} \mathrm{M} / \mathrm{ml}$ & Imran Khan et al. [29] \\
\hline 17 & Food waste & Saccharomyces cerevisiae & $30^{\circ} \mathrm{C}$ & Yield $-0.39 \mathrm{~g} / \mathrm{g}$ & $\begin{array}{c}\text { Oya Nihan Uncu, \& Deniz } \\
\text { Cekmecelioglu [30] }\end{array}$ \\
\hline 18 & Glucose and Xylose & Saccharomyces cerevisiae & -- & $37.1 \pm 0.5$ & Ishola et al. [17] \\
\hline 19 & Sweet sorghum bagasse (SSB) & Pichia kudriavzevii & -- & 26.02 & Lavudi et al. [18] \\
\hline 20 & Yellow poplar & Pichia stipitis CBS 6054 & -- & 34.54 & Jeong \& Lee [19] \\
\hline
\end{tabular}

Table 2: Ethanol production from various lignocellulosic biomass. 
Citation: Tripathi S (2018) Optimization of Fermentation Conditions for Ethanol Production from Renewable Biomass Using Response Surface Methodology. J Pet Environ Biotechnol 9: 379. doi: 10.4172/2157-7463.1000379

Page 4 of 9

as xylose is an important component of most agricultural residues. They used the genetically modified strain of S. cerevisiae T0936 and employed Simultaneous Saccharification, Filtration and Fermentation technique for simultaneous utilization of glucose and xylose. They also tested the elimination of bacterial contamination by high solid loading and inhibitory medium effect on the modified strain of bacteria used [17]. This paper basically focuses on optimization of condition through response surface methodology for production of ethanol from sweet sorghum bagasse as it is cheap and widely available resource. They performed a two stage optimization, in first they chose conditions for pre-treatment and at second stage they chose different conditions for enzymatic hydrolysis so that they could setup a parameter for further scale up studies [18]. The study in the paper was to find the optimal

\begin{tabular}{|c|c|c|}
\hline Water $\mathbf{( m )}$ & Stock Solution $\mathbf{( m l )}$ & Total Volume $(\mathbf{m l})$ \\
\hline 10 & 0 & 10 \\
\hline 9 & 1 & 10 \\
\hline 8 & 2 & 10 \\
\hline 7 & 3 & 10 \\
\hline 6 & 4 & 10 \\
\hline 5 & 5 & 10 \\
\hline 4 & 6 & 10 \\
\hline 3 & 7 & 10 \\
\hline
\end{tabular}

Table 3: DNSA experiment table.

\begin{tabular}{|c|c|c|}
\hline S. No. & Glucose Concentration & Absorption at $\mathbf{5 4 0} \mathbf{~ m m}$ \\
\hline 1 & 0 & 0.002 \\
\hline 2 & 1 & 0.124 \\
\hline 3 & 2 & 0.164 \\
\hline 4 & 3 & 0.203 \\
\hline 5 & 4 & 0.301 \\
\hline 6 & 5 & 0.336 \\
\hline 7 & 6 & 0.361 \\
\hline 8 & 7 & 0.464 \\
\hline 9 & 8 & 0.479 \\
\hline
\end{tabular}

Table 4: Reducing sugar estimation. pre-treatment condition at which yellow poplar can be used for ethanol production by simultaneous saccharification and fermentation with the help of response surface methodology. Combined severity factor of pretreated biomass was one of the main factors to check the effect increasing acid concentration with time [19]. This study is on Pterocladiella capillacea as a third-generation biomass for bioethanol production. They performed optimization of saccharification by sulfuric acid and its detoxification. For fermentation yeast Kluyveromyces marxianus was used as it is thermo tolerant, higher growth rate and has broad substrate spectrum [20]. Seaweeds contain a variety of monomeric sugar making it a potential substrate for bioethanol production. This study was done to find out the microorganism which could ferment these sugars in seaweed and its hydrolysate into ethanol [21]. They used the plant Phragmites australis (a perennial grass) as a source of ethanol production due to its high cellulose content, fast growth, high biomass yields and low nutrient \& water requirements. Technique of steam explosion was used for pre-treatment as it requires low capital investment and gives complete sugar recovery. Optimization of result was done through RSM and Pre saccharification and simultaneous saccharification and fermentation was done to get improved ethanol yield [6] (Table 2).

\section{Materials and Methods}

Potato Peel Waste (PPW) was collected from the household wastes and local food vendors from Lovely Professional University, Punjab. The PPW was washed properly with running water to remove any unwanted dust particles. It was air dried for a period of 1-2 days and then dried in hot air oven at a temperature of $110^{\circ} \mathrm{C}$ for 2 hours so as to remove excess moisture. The dried PPW was then grinded with Pestle and Mortar and converted to a fine powder and was stored at room temperature till required.

Two duplicates of the solutions were prepared to check for best results. The simultaneous acid-base pre-treatment method for lignocellulosic biomass has been effective in removal of hemicellulose and lignin ultimately releasing high amount of fermentable carbohydrates, which could be further carried out by enzymatic hydrolysis [22-31] (Figure 3).

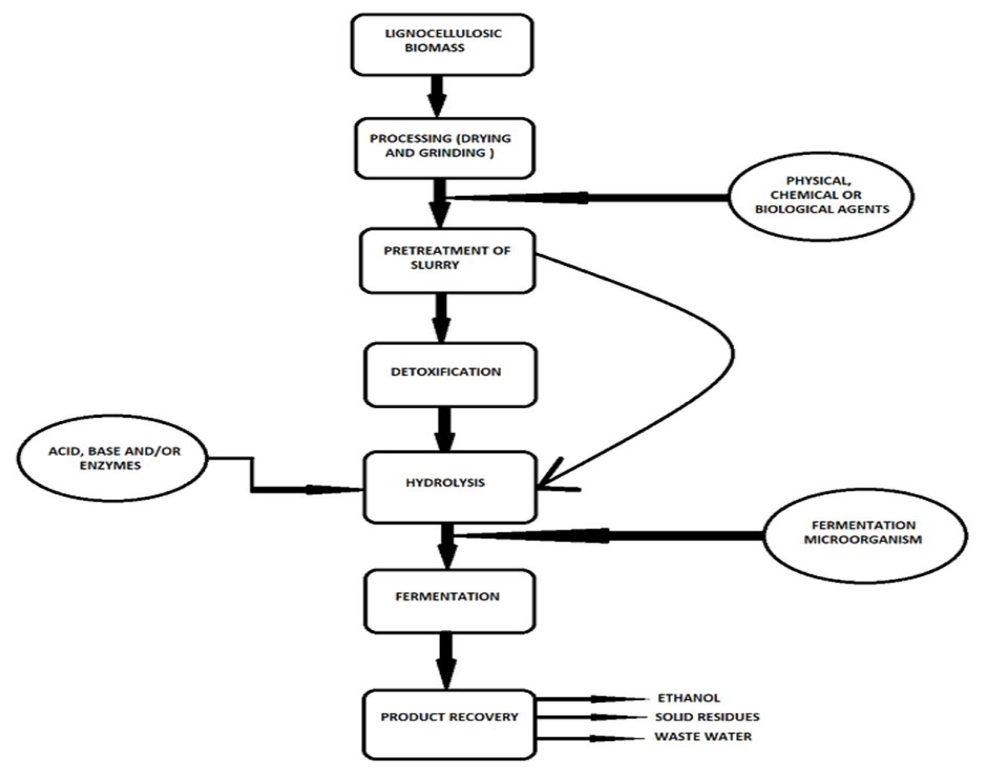

Figure 3: Flowchart representation of process/methodology adopted in ethanol production by response surface methodology. 
Citation: Tripathi S (2018) Optimization of Fermentation Conditions for Ethanol Production from Renewable Biomass Using Response Surface Methodology. J Pet Environ Biotechnol 9: 379. doi: 10.4172/2157-7463.1000379

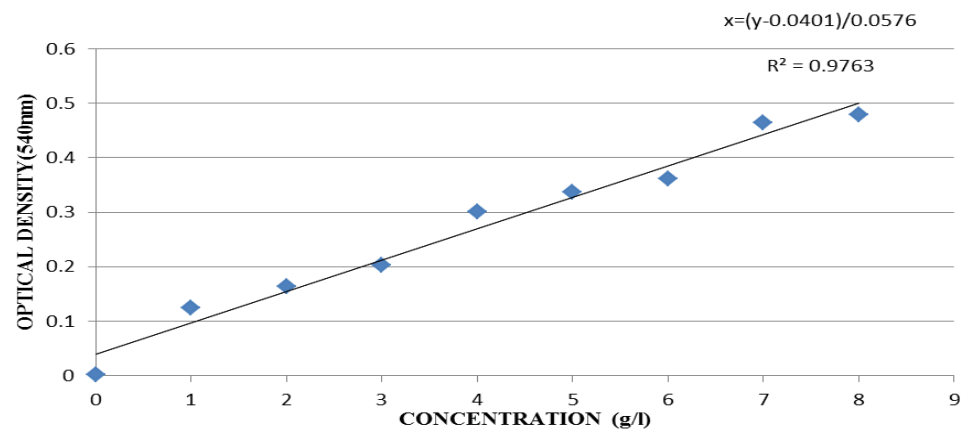

Figure 4: DNSA method graph.

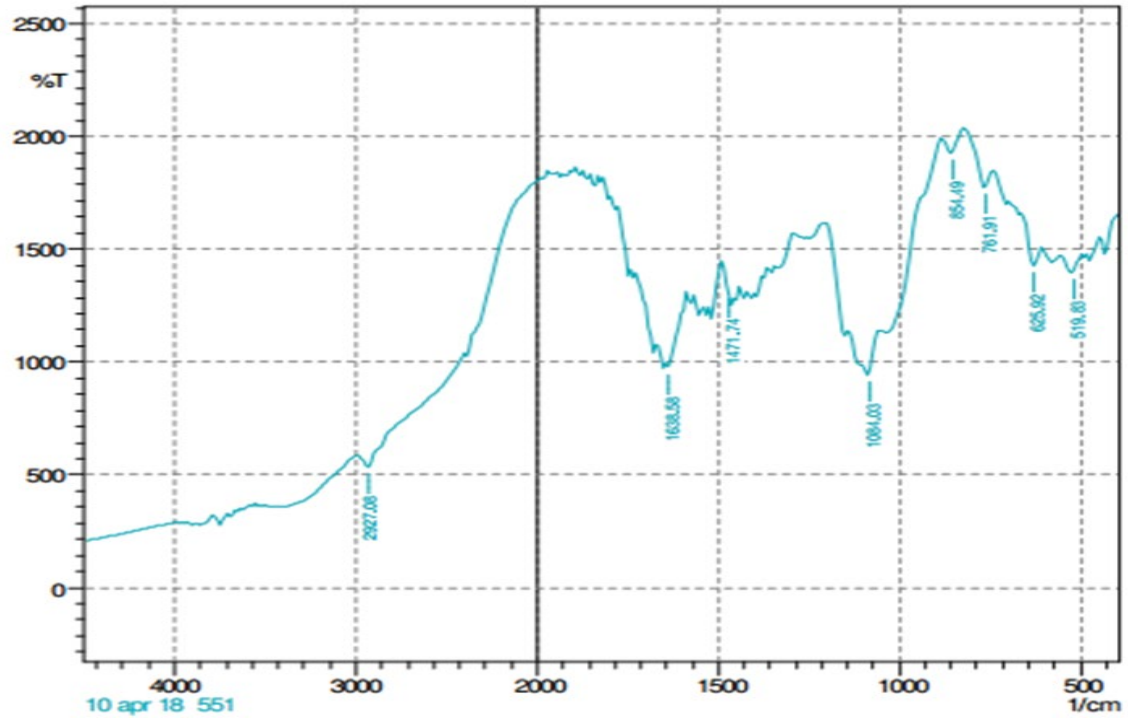

Figure 5: Graph for un-treated biomass.

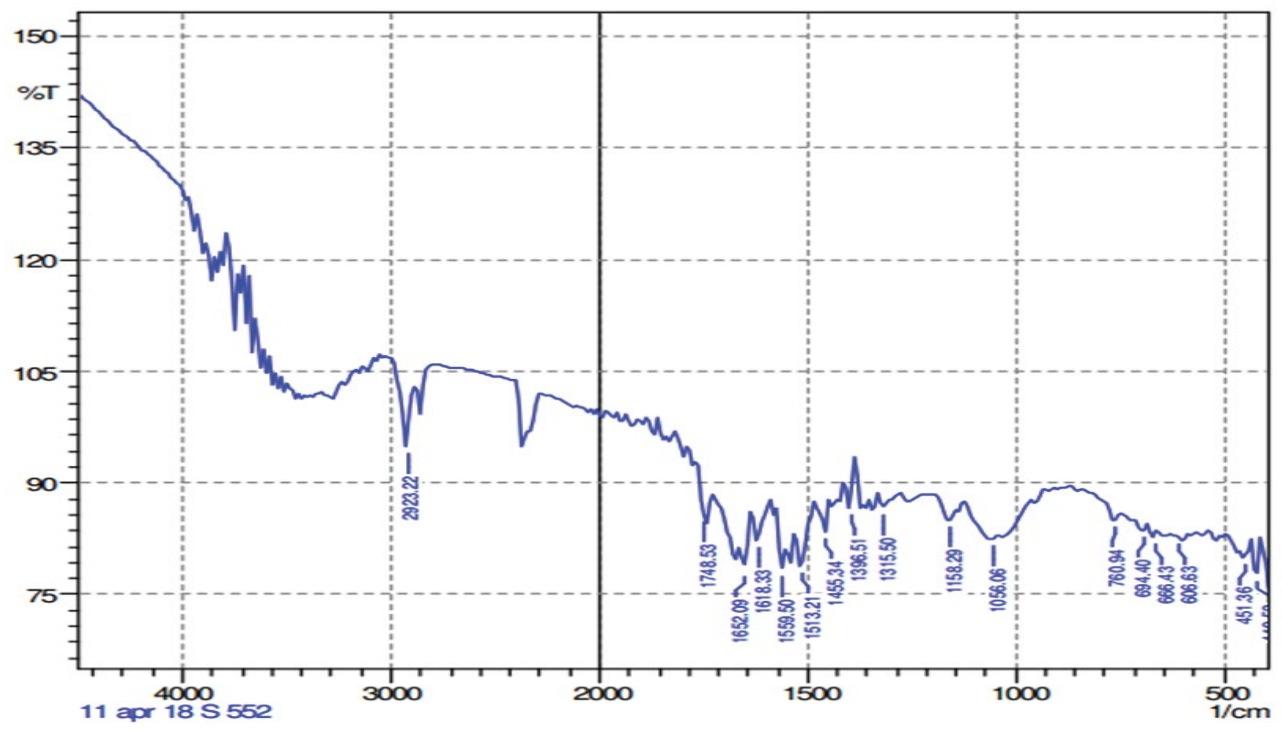

Figure 6: Graph for treated hydrolysate. 
Citation: Tripathi S (2018) Optimization of Fermentation Conditions for Ethanol Production from Renewable Biomass Using Response Surface Methodology. J Pet Environ Biotechnol 9: 379. doi: 10.4172/2157-7463.1000379

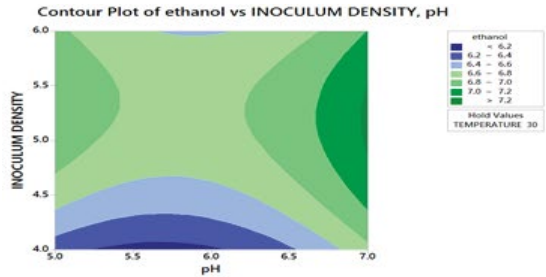

Surface Plot of ethanol vs TEM PERATURE, ph

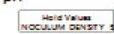

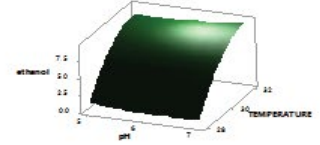

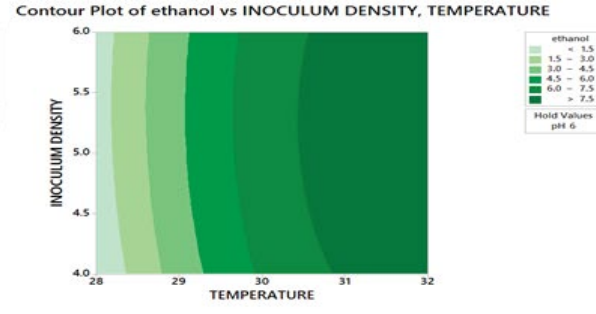

Surface Plot of ethanol vs INOCULUM DENSITY, TEMPERATURE

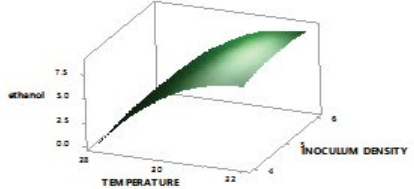

Contour Plot of ethanol vs TEMPERATURE, pH

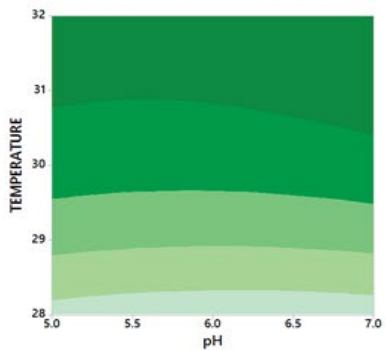

Surface Plot of ethanol vs INOCULUM DENSITY, pH

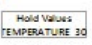

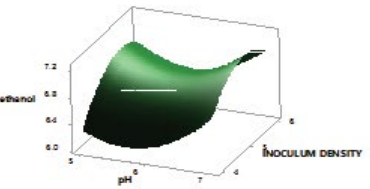

Figure 7: Response surface methodology plots (Contour and surface plots).

\begin{tabular}{|c|c|c|c|c|c|c|c|}
\hline S. No & Peak & Intensity & Corr. Inte & Base (H) & Base (L) & Area & Corr. Area \\
\hline 1 & 519.83 & 1393.9 & 21.1 & 525.62 & 503.44 & -25.5 & 0.1 \\
\hline 2 & 625.92 & 1428.3 & 141.4 & 658.71 & 603.74 & -64.8 & 1.1 \\
\hline 3 & 761.91 & 1773.5 & 133.3 & 818.81 & 739.73 & -101 & 1 \\
\hline 4 & 854.49 & 1926.6 & 85.7 & 881.5 & 818.81 & -81.2 & 0.6 \\
\hline 5 & 1084.03 & 944.2 & 95 & 1100.43 & 1051.24 & -49.7 & 0.7 \\
\hline 6 & 1471.74 & 1313.9 & 12 & 1480.42 & 1470.77 & -10.9 & 0 \\
\hline 7 & 1638.58 & 974.7 & 22.1 & 1640.51 & 1631.83 & -8.6 & 0 \\
\hline 8 & 2927.08 & 532 & 71.9 & 2990.73 & 2872.1 & -89.8 & 2.7 \\
\hline
\end{tabular}

Table 5: FTIR reference table for un-treated biomass.

\begin{tabular}{|c|c|c|c|c|c|c|c|}
\hline No & Peak & Intensity & Corr. Inte & Base (H) & Base (L) & Area & Corr. Area \\
\hline 1 & 419.53 & 77.56 & 5.184 & 432.07 & 406.99 & 2.451 & 0.389 \\
\hline 2 & 451.36 & 79.974 & 0.497 & 456.18 & 447.5 & 0.83 & 0.012 \\
\hline 3 & 606.63 & 82.61 & 0.117 & 613.38 & 604.7 & 0.714 & 0.003 \\
\hline 4 & 666.43 & 82.812 & 1.162 & 681.86 & 655.82 & 2.067 & 0.102 \\
\hline 5 & 694.4 & 83.524 & 1.17 & 711.76 & 681.86 & 2.251 & 0.1 \\
\hline 6 & 760.94 & 84.945 & 1.244 & 838.1 & 749.37 & 5.172 & -0.014 \\
\hline 7 & 1056.06 & 82.362 & 1.194 & 1107.18 & 1040.63 & 5.209 & 0.273 \\
\hline 8 & 1158.29 & 84.911 & 2.196 & 1191.08 & 1138.04 & 3.386 & 0.269 \\
\hline 9 & 1315.5 & 86.708 & 1.605 & 1327.07 & 1300.07 & 1.591 & 0.126 \\
\hline 10 & 1396.51 & 86.607 & 5.038 & 1407.12 & 1384.94 & 1.106 & 0.271 \\
\hline 11 & 1455.34 & 83.292 & 2.603 & 1460.16 & 1443.77 & 1.16 & 0.122 \\
\hline 12 & 1513.21 & 78.74 & 2.145 & 1519.96 & 1508.38 & 1.148 & 0.093 \\
\hline 13 & 1559.5 & 78.275 & 2.999 & 1572.04 & 1555.64 & 1.487 & 0.165 \\
\hline 14 & 1618.33 & 82.126 & 3.474 & 1629.9 & 1602.9 & 2.04 & 0.217 \\
\hline 15 & 1652.09 & 78.397 & 1.479 & 1659.8 & 1649.19 & 1.054 & 0.045 \\
\hline 16 & 1748.53 & 85.8 & 0.6 & 1762.03 & 1747.57 & 0.736 & 0.026 \\
\hline 17 & 2923.22 & 94.816 & 9.627 & 2993.62 & 2879.82 & -0.715 & 1.65 \\
\hline
\end{tabular}

Table 6: FTIR reference table for treated biomass.

\begin{tabular}{|c|c|c|}
\hline S. No. & Sample & Concentration (G/L) \\
\hline 1. & Sample 1 & 0.50 \\
\hline 2. & Sample 2 & 5.97 \\
\hline 3. & Sample 3 & 6.80 \\
\hline 4. & Sample 4 & 6.90 \\
\hline 5. & Sample 5 & 7.32 \\
\hline 6. & Sample 6 & 8.00 \\
\hline 7. & Sample 7 & 8.90 \\
\hline
\end{tabular}

Table 7: Titration results.

\section{Acid pre-treatment}

Reagent used: $1 \%$ and $2 \% \mathrm{H}_{2} \mathrm{SO}_{4}(\mathrm{v} / \mathrm{v})$ solution has been prepared.

Acid pre-treatment is used because it's inexpensive as the availability of the acid used is widely available and at a cheap cost. Mainly Sulphuric acid is used for acid treatment. The treatment of lignocellulosic biomass by using dilute Sulphuric acid is a rapid and effective process for the removal of hemicellulose from it, thereby leaving only cellulose and lignin together in a complex form known as 
Citation: Tripathi S (2018) Optimization of Fermentation Conditions for Ethanol Production from Renewable Biomass Using Response Surface Methodology. J Pet Environ Biotechnol 9: 379. doi: 10.4172/2157-7463.1000379

Page 7 of 9

\begin{tabular}{|c|c|c|c|c|c|}
\hline Source & DF & Adj SS & Adj MS & F-Value & p-value \\
\hline Model & 9 & 140.681 & 15.631 & 79.67 & 0 \\
\hline Linear & 3 & 123.536 & 41.179 & 209.88 & 0 \\
\hline $\mathrm{pH}$ & 1 & 0.186 & 0.186 & 0.95 & 0.375 \\
\hline Temperature & 1 & 123.01 & 123.01 & 626.97 & 0 \\
\hline Inoculum Density & 1 & 0.34 & 0.34 & 1.73 & 0.245 \\
\hline Square & 3 & & 5.565 & 28.36 & 0.001 \\
\hline $\mathrm{pH} \times \mathrm{pH}$ & 1 & 0.437 & 0.437 & 2.23 & 0.196 \\
\hline Temperature $\times$ Temperature & 1 & 15.567 & 15.567 & 79.35 & 0 \\
\hline Inoculum Density $\times$ Inoculum Density & 1 & 0.448 & 0.448 & 2.28 & 0.191 \\
\hline 2-Way Interaction & 3 & 0.45 & 0.15 & 0.76 & 0.561 \\
\hline $\mathrm{pH} \times$ Temperature & 1 & 0.403 & 0.403 & 2.06 & 0.211 \\
\hline $\mathrm{pH} \times$ Inoculum Density & 1 & 0.024 & 0.024 & 0.12 & 0.741 \\
\hline Temperature $\times$ Inoculum Density & 1 & 0.023 & 0.023 & 0.11 & 0.749 \\
\hline Error & 5 & 0.981 & 0.196 & -- & -- \\
\hline Lack-of-Fit & 3 & 0.897 & 0.299 & 7.09 & 0.126 \\
\hline Pure Error & 2 & 0.084 & 0.042 & -- & -- \\
\hline Total & 14 & 141.662 & -- & -- & -- \\
\hline
\end{tabular}

(a) ANOVA results.

\begin{tabular}{|c|c|c|c|}
\hline S & R-sq. & & R-sq.(pred) \\
\hline 0.442943 & $99.31 \%$ & $98.06 \%$ & $89.74 \%$ \\
\hline
\end{tabular}

(b) Model summary

\begin{tabular}{|c|c|c|c|c|c|}
\hline Term & Coef & SE Coef & T-Value & p-value & VIF \\
\hline Constant & 6.727 & & 26.3 & 0 & \\
\hline $\mathrm{pH}$ & 0.153 & 0.157 & & 0.375 & 1 \\
\hline Temperature & 3.921 & 0.157 & 25.04 & 0 & 1 \\
\hline Inoculum Density & 0.206 & 0.157 & 1.32 & 0.245 & 1 \\
\hline $\mathrm{pH} \times \mathrm{pH}$ & 0.344 & 0.231 & 1.49 & 0.196 & 1.01 \\
\hline Temperature $\times$ Temperature & -2.053 & 0.231 & -8.91 & 0 & 1.01 \\
\hline $\begin{array}{l}\text { Inoculum Density x } \\
\text { Inoculum Density }\end{array}$ & -0.348 & 0.231 & -1.51 & 0.191 & 1.01 \\
\hline $\mathrm{pH} \times$ Temperature & 0.318 & 0.221 & 1.43 & 0.211 & 1 \\
\hline $\mathrm{pH} \times$ Inoculum Density & -0.077 & 0.221 & -0.35 & 0.741 & 1 \\
\hline $\begin{array}{c}\text { Temperature } \times \text { Inoculum } \\
\text { Density }\end{array}$ & -0.075 & 0.221 & -0.34 & 0.749 & 1 \\
\hline \multicolumn{6}{|c|}{$\begin{array}{l}\text { Regression equation in uncoded units } \\
\text { Ethanol }=-491.7-8.35 \mathrm{pH}+32.00 \text { Temperature }+5.28 \text { Inoculum Density }+ \\
0.344 \mathrm{pH} \times \mathrm{pH}-0.5133 \mathrm{Temperature} \times \text { Temperature }-0.348 \text { Inoculum Density } \\
\times \text { Inoculum Density }+0.159 \mathrm{pH} \times \text { Temperature }-0.077 \mathrm{pH} \times \text { Inoculum Density }- \\
0.038 \text { Temperature } \times \text { Inoculum Density. }\end{array}$} \\
\hline
\end{tabular}

(c) Coded coefficients

Table 8: Response surface methodology results.

cellulignin [32]. This test can be carried out at different concentrations and at different temperatures.

For acid pre-treatment, the chemical used here is $\mathrm{H}_{2} \mathrm{SO}_{4}$ : The constituents added in the $250 \mathrm{ml}$ flask were $24 \mathrm{~g}$ PPW which was dissolved in $120 \mathrm{ml}$ distilled water containing $1 \%$ and $2 \% \mathrm{H}_{2} \mathrm{SO}_{4}$. Sterilization of both the mixtures are done in at $121^{\circ} \mathrm{C}$, over a time period of 40 minutes (for $1 \% \mathrm{H}_{2} \mathrm{SO}_{4}$ ) and 60 minutes (for $2 \% \mathrm{H}_{2} \mathrm{SO}_{4}$ ) respectively. Solutions must be cooled to $\mathrm{T}<40^{\circ} \mathrm{C}$ and neutralized under using tap water and filtered. The $\mathrm{pH}$ of both the samples is adjusted between; 6.9-7.1 for optimum growth of yeast.

\section{Alkali pre-treatment}

Reagent used: $1 \%$ and $2 \% \mathrm{NaOH}(\mathrm{w} / \mathrm{v})$ solution has been prepared.

Potato peel is a by-product, containing a high level of starch, cellulose and hemicelluloses. The alkali used here is $\mathrm{NaOH}$. The $\mathrm{NaOH}$ helps dissolve carbohydrates. It is used thereby for biological conversion of cellulose into glucose. Pre-treatment done for PPW at lower temperatures enhances the process [33].

In this experiment $1 \%$ and $2 \% \mathrm{NaOH}$ solutions were used for pretreatment. The constituents added in the $500 \mathrm{ml}$ beaker were $\mathrm{NaOH}$ solution was added to $24 \mathrm{~g}$ PPW which was dissolved in $120 \mathrm{ml}$ distilled water having $1 \%$ and $2 \% \mathrm{NaOH}$. All the constituents were treated at $100^{\circ} \mathrm{C}$ for 1 hour. The treated solution was then cooled down to $\mathrm{T}<40^{\circ} \mathrm{C}$ and then neutralized with tap water and filtered. The filtrate was used for further enzymatic hydrolysis treatment.

\section{Enzymatic hydrolysis}

The enzymatic hydrolysis of PPW was done with two-component enzyme system. Two enzymes, $\alpha$-amylase (E.C. 3.2.1.1) and amyloglucosidase (E.C. 3.2.1.3), are used as the best treatment method applicable for enzymatic hydrolysis of lignocellulosic mass and starch treatment. $\alpha$-amylase specifically catalyzes the hydrolysis of $\alpha-1,4$ glycosidic bonds in starch to dextrins, maltose, and a small amount of glucose. Then amyloglucosidase catalyzes the hydrolysis of maltose and higher DP (degree of polymerization) maltodextrins to glucose since it can hydrolyze $\alpha-1,6$ linkages [31].

To $100 \mathrm{mg}$ of dry potato peel hydrolysate (obtained from previous acid-base treatments), $100 \mu \mathrm{l} \alpha$-amylase enzyme solution and $100 \mu \mathrm{l}$ of amyloglucosidase solution, containing different ranges of enzyme concentration, was used. The ratio of $a$-amylase to amyloglucosidase enzyme was taken fixed at 15:1 and evenly used for starch treatment. The PPW was then treated by enzyme hydrolysis for 48 hours at $37^{\circ} \mathrm{C}$.

\section{Estimation of glucose concentration by DNSA method}

\section{Preparation of reagents:}

3, 5-dinitrosalicylic acid [DNS]-DNS reagent composition (for $100 \mathrm{ml}$ )

$\checkmark$ Sodium hydroxide: $1 \mathrm{~g}$

$\checkmark$ Sodium potassium tartarate: $19.2 \mathrm{~g}$

$\checkmark$ Dinitro salicylic acid: $1 \mathrm{~g}$

D Phenol: $0.2 \mathrm{~g}$

$\checkmark$ Sodium sulphite: $0.05 \mathrm{~g}$ 
Citation: Tripathi S (2018) Optimization of Fermentation Conditions for Ethanol Production from Renewable Biomass Using Response Surface Methodology. J Pet Environ Biotechnol 9: 379. doi: 10.4172/2157-7463.1000379

$D$ Make up the volume to $100 \mathrm{ml}$ with distilled water.

D Stock Solution of Glucose -1000 ppm $=1000 \mathrm{mg} / \mathrm{l}$

Working solution $-100 \mathrm{ppm}=100 \mathrm{mg} / 100 \mathrm{ml}$

- Take 8 clean test tubes and add $0 \mathrm{ml}, 1 \mathrm{ml}, 2 \mathrm{ml}, 3 \mathrm{ml}, 4 \mathrm{ml}, 5 \mathrm{ml}, 6$ $\mathrm{ml}$, and $7 \mathrm{ml}$ of standard glucose solution and label the test tubes. Now, make up the volume $10 \mathrm{ml}$ in each test tube. Add $1 \mathrm{ml}$ of DNS to each test tube. Incubate the test tubes in boiling water for 10 minutes. Take spectrophotometer reading at $540 \mathrm{~nm}$. After getting the results we plot the graph by plotting glucose amount on $\mathrm{X}$-axis and optical density on y-axis (Table 3 ).

\section{Determination of ethanol concentration by titration}

D Acid dichromate solution $(0.01 \mathrm{~mol} / \mathrm{L}$ in $5.0 \mathrm{~mol} / \mathrm{L}$ Sulphuric acid $)$

D Starch indicator solution (1.0\% solution)

D Sodium thiosulphate $(0.03 \mathrm{~mol} / \mathrm{L})$

$\checkmark$ Potassium iodide solution $(1.2 \mathrm{~mol} / \mathrm{L})$

Dilute the solution samples in 1:20 $(10 \mathrm{ml}$ in $200 \mathrm{ml})$ with distilled water. To a $250 \mathrm{ml}$ conical flask, add $10 \mathrm{ml}$ of acid dichromate solution and seal flask with rubber stopper. To a $5 \mathrm{ml}$ beaker, pipette out $1 \mathrm{ml}$ of sample solution and prepare three samples accordingly. Suspend the $5 \mathrm{ml}$ beaker over the acid dichromate solution. Incubate the flask overnight at $25-30^{\circ} \mathrm{C}$. After incubation, keep the flask at room temperature and loosen the stopper and discard the $5 \mathrm{ml}$ beaker. Rinse the walls with distilled water; add to it about $100 \mathrm{ml}$ of distilled water and $1 \mathrm{ml}$ of potassium iodide solution and vortex slightly to mix. Prepare 3 blank titrations of same by adding $10 \mathrm{ml}$ of acid dichromate solution and $100 \mathrm{ml}$ of distilled water and $1 \mathrm{ml}$ potassium iodide solution and mix it. Fill the sodium thiosulphate solution in the burette and titrate against each solution. Add $1 \mathrm{ml}$ of starch solution when the color of solution changes to yellow and titrate until the blue color disappears (Table 4).

\section{Results and Discussion}

\section{Concentration vs. Absorbance}

This graph is the standard glucose curve. The given graph provides us our samples concentration obtained after biomass acid-base and enzymatic treatment (Figure 4).

Sample 1: -Absorbance - 2.908; Concentration - 48.7189 g/l.

FTIR analysis was performed to check the presence of functional group and do the comparative study of the functional groups in the raw material and hydrolysate (Tables 5 and 6). For the raw sample, the peak at $2927.08 \mathrm{~cm}^{-1}$ shows presence of medium CarbonHydrogen stretching vibration bond. $1638.58 \mathrm{~cm}^{-1}$ peak is for the presence of monosubstituted alkene $(-\mathrm{C}=\mathrm{C}-)$ (Figure 5). The peak at $1084.03 \mathrm{~cm}^{-1}$ show strong stretching of $-\mathrm{C}-\mathrm{O}$ - bond and confirms the presence of primary alcohol groups in the sample. While the notable difference in the peaks of hydrolysate is visible at $1748.53 \mathrm{~cm}^{-1}$, which represents strong stretching of esters and also the peaks at 1652.09 $\mathrm{cm}^{-1}$ medium stretching of cyclic alkene, $1618.33 \mathrm{~cm}^{-1}$ strong stretching of $\alpha, \beta$-unsaturated ketone (Figures 6 and 7). One of the important differences is noted in $1395.91 \mathrm{~cm}^{-1}$ peak which is for medium bending of aldehyde groups. The broad peak at $1056.06 \mathrm{~cm}^{-1}$ in hydrolysate graph shows strong stretching of anhydride group (Tables 7 and 8).

\section{Conclusion}

Lignocellulosic biomass proved to be an efficient source for secondgeneration biofuels, as an alternative to petroleum-oil based fossil fuels. The utilization of agricultural wastes, household wastes and industrial solid residues for bioethanol production is a highly cost-efficient and potentially environment-sustainable approach for coping up with the ever-increasing global energy demands. As far as the needs of alternative fuels are concerned, the recent research progress in enzyme production outputs, the pre-treatment methodologies involved and the metabolic engineering and analysis of yeasts.

\section{Acknowledgements}

I express my sincere gratitude to The Head of School of Department of Biotechnology, Lovely Professional University, Dr. Neeta Raj Sharma, for providing me such an opportunity in the field of Bioprocess engineering in a prestigious institute of national repute.

A heart full thanks and deep sense of gratitude to Mr. Ajay Kumar for being a constant backbone and highly supportive mentor. His uninterrupted guidance has made this project highly successful.

I express my deep appreciation to all technical members like Mr. Devendra and non-technical laboratory members like Mr. Upkar Singh of the Department of Biotechnology, Lovely Professional University for their cooperative and friendly behavior.

I owe a very special thanks to my parents who were behind me throughout our project encouraging me to perform my best. Their unwavering faith, help and determination for work has made my project a successful experience. Though my words could not convey it all, still it was an attempt to express my heartfelt gratitude to everyone who made this project successful.

\section{References}

1. Hao J, Lin R, Zheng Z, Sun Y, Liu D (2008) 3-hydroxypropionaldehyde guided glycerol feeding strategy in aerobic 1,3-propanediol production by Klebsiella pneumoniae. J Ind Microbiol Biotechnol 35: 1615-1624.

2. Aguilar R, Ramirez JA, Garrote G, Vazquez M (2002) Kinetic study of acid hydrolysis of sugar cane bagasse. J Food Eng 55:309-318.

3. Gamez S, Juan Cabriales JG, Ramírez JA, Garrote G, Vazquez M (2006) Study of the hydrolysis of sugar cane bagasse using phosphoric acid, J Food Eng 74: 78-88.

4. Herrera A, Tellez-Luis SJ, Ramrez JA, Vazquez M (2003) Production of xylose from sorghum straw using hydrochloric acid. J Cer Sci 37:267-274.

5. Agbogbo FK, Wenger KS (2007) Production of ethanol from corn stover hemicellulose hydrolysate using Pichia stipitis. J Ind Microbiol Biotechnol 34:723-7.

6. Cavalaglio G, Gelosia M, Ingles D, Pompili E, D'Antonio S, et al. (2016) Response surface methodology for the optimization of cellulosic ethanol production from Phragmites australis through pre-saccharification and simultaneous saccharification and fermentation. Ind Crop Prod 83: 431- 437.

7. Chandel AK, Antunes AF, Anjos V, Rodrigues, Bell MJV, et al. (2014) Multiscale structural and chemical analysis of sugarcane bagasse in the process of sequential acid-base pretreatment and ethanol production by Scheffersomyces shehatae and Saccharomyces cerevisiae. Biotechnol biofuels 7: 63 .

8. Liu (2002) A study of enzymatic hydrolysis of starch in potato pulp. J Food Sci 67: 2113-2117.

9. Wang JG, Zhang SZ, Yang BP, Cheng P, Wu ZD, et al. (2008) Application of 3,5-dinitrosalicylic acid (DNS) method to test the reducing sugar and water-soluble total sugar content in sugarcane internodes. J Sugarcane and Canesugar 5: 45-49.

10. Hamouda IH, Nassar HN, Madian HR, Amr Salem SA, El-Gendy R (2015) Response surface optimization of bioethanol production from sugarcane molasses by Pichia Veronae strain HSC-22. Biotechnol Res int 2015:1-10.

11. Wang F, Jiang Y, Guo W, Niu K, Zhang R, et al. (2016) An environmentally friendly and productive process for bioethanol production from potato waste. Biotechnol Biofuels 9: 50

12. Jitrwung R, Yargeau $V$ (2015) Biohydrogen and bioethanol production from 
Citation: Tripathi S (2018) Optimization of Fermentation Conditions for Ethanol Production from Renewable Biomass Using Response Surface Methodology. J Pet Environ Biotechnol 9: 379. doi: 10.4172/2157-7463.1000379

Page 9 of 9

biodiesel-based glycerol by Enterobacter aerogenes in a continuous stir tank reactor. Int J Mol Sci 16: 10650-10664

13. El-Gendy NS, Madian HR, Amr SA (2013) Design and optimization of a process for sugarcane molasses fermentation by Saccharomyces cerevisiae using response surface methodology. Int J Microbiol 2013:

14. Zhang Q, Weng C, Huang H, Achal V, Wang D (2016) Optimization of bioethano production using whole plant of water hyacinth as substrate in simultaneous saccharification and fermentation process. Front Microbiol 6: 1411.

15. Neifar M, Chouchane H, Masmoudi AS, Genouiz R, Jaouani A, et al. (2016) Improved sugar yield for bioethanol production by modelling enzymatic hydrolysis of Peganum Harmala biomass through response surface methodology. Int J Eng Sci 5:22-28

16. Khan MI, Lee MG, Shin JH, Kim JD (2017) Pre-treatment optimization of the biomass of Microcystis aeruginosa for efficient bioethanol production. AMB Expr 7:19.

17. Ishola MM, Brandberg T, Taherzadeh MJ (2015) Simultaneous glucose and xylose utilization for improved ethanol production from lignocellulosic biomass through SSFF with encapsulated yeast. Biomass Bioener 77:192-199.

18. Lavudi S, Oberoi HS, Mangamoori LN (2017) Ethanol production from sweet sorghum bagasse through process optimization using response surface methodology. 3 Biotech 7: 233.

19. Jeong SY, Lee JW (2016) Optimization of pre-treatment condition for ethanol production from oxalic acid pretreated biomass by response surface methodology. Ind Crop Prod 79:1-6.

20. Wu CH, Chien CW, Chou HK, Yang J, Victor Lin HT (2014) Sulfuric acid hydrolysis and detoxification of red alga Pterocladiella capillacea for bioethano fermentation with thermotolerant yeast Kluyveromyces marxianus. J Microbio Biotechnol 24:1245-1253.

21. Kostas ET, White DA, DuC, Cook DJ (2016) Selection of yeast strains for bioethanol production from UK seaweeds. J Appl Phycol 28:1427-1441.

22. Ho SH, Chen YD, Chang CY, Lai YY, Chen CY, et al. (2017) Feasibility of CO mitigation and carbohydrate production by microalga Scenedesmus obliquus
CNW-N used for bioethanol fermentation under outdoor conditions: effects of seasonal changes. Biotechnol Biofuels 10:27.

23. Azhar SHM, Abdulla R, Jambo SA, Marbawi H, Gansau JA, et al. (2017) Yeasts in sustainable bioethanol production: A review. Biochem Biophysics Rep 10:52-61.

24. Engelhardt H (2012) High performance liquid chromatography. Springer Science \& Business Media, Berlin, Germany.

25. Saini JK, Saini R, Tewari L (2015) Lignocellulosic agriculture wastes as biomass feedstocks for second-generation bioethanol production: concepts and recent developments. 3 Biotech 5:337-353.

26. Saini JK, Saini R, Tewari R (2014) Lignocellulosic agriculture wastes as biomass feedstocks for second-generation bioethanol production: concepts and recent developments. 3 Biotech 5: 337-353

27. Trivedi N, Reddy CR, Radulovich R, Bhavanath J (2015) Solid state fermentation (SSF)-derived cellulase for saccharification of the green seaweed Ulva for bioethanol production. Algal Res 9:48-54.

28. Saha BC, Kennedy GJ, Qureshi N, Cotta MA (2017) Biological pre-treatment of corn Stover with Phlebia brevispora NRRL $\square 13108$ for enhanced enzymatic hydrolysis and efficient ethanol production. Biotechnol Prog 33:365-374.

29. Khan MI, Lee MG, Shin HJ, Kim DJ (2017) Pre-treatment optimization of the biomass of Microcystis aeruginosa for efficient bioethanol production. AMB Expr 7:19.

30. Oya NU, Cekmecelioglu D (2011) Cost-effective approach to ethano production and optimization by response surface methodology. Waste Manage 31: $636-643$.

31. Zhang YP, Lynd LR (2004) Toward an aggregated understanding of enzymatic hydrolysis of cellulose: noncomplexed cellulase systems. Biotechnol Bioeng 88: 797-824.

32. Betancur GJV, Pereira N (2010) Sugar cane bagasse as feedstock for second generation ethanol production. Part I: diluted acid pre-treatment optimization. Electron J Biotechnol 13: 1-9.

33. Jackson MG (1997) Review article: The alkali treatment of straws. Anim Feed Sci Technol 2: 105-130. 